\title{
Political Involvement in "Mobilized" Society: The Interactive Relationships Among Mobile Communication, Network Characteristics, and Political Participation
}

\author{
Scott W. Campbell \& Nojin Kwak
}

Department of Communication Studies, University of Michigan, Ann Arbor, MI 48104, USA

\begin{abstract}
In recent years, mobile communication has emerged as a channel for political discourse among network ties. Although some celebrate new possibilities for political life, others are concerned that it can lead to network insularity and political detachment. This study examined how mobile-mediated discourse with strong ties interacts with characteristics of those ties to predict levels of political participation. Findings revealed that mobile-based discourse is positively associated with political participation, but that this relationship is moderated by the size and heterogeneity of one's network. Participation increases with use of the technology in large networks of like-minded individuals, but declines with use of the technology in homogeneous networks that are small. Implications and future research considerations are offered in the discussion.
\end{abstract}

doi:10.1111/j.1460-2466.2011.01601.x

Discussion networks have been a central concern in scholarship on the democratic process because they influence various aspects of political life, including participation levels. Frequency of political discourse, number of network ties, and the extent to which those ties are like minded can all affect political participation (Eveland \& Hively, 2009; Kwak, Williams, Wang, \& Lee, 2005; Mutz, 2002). Most of the research in this area has considered overall frequency of political discussion, with the assumption that it occurs in a face-to-face context (Hardy \& Scheufele, 2005). With the extension of interpersonal communication through new media, scholars have begun to explore the implications of specific channels for political discourse, particularly computermediated communication (CMC; Hardy \& Scheufele, 2006). This study extends the research by examining how mobile-mediated discourse intersects with the size and like-mindedness of network ties to predict levels of political participation during the 2008 U.S. presidential election. As Kwak et al. (2005) explain, these two network

Corresponding author: Scott W. Campbell; e-mail: swcamp@umich.edu 
characteristics, along with discussion frequency, comprise the "three most researched structural features of political discussion" (p. 104). Analysis of national survey data from this study reveals that, after controlling for other modes of discourse, use of the mobile phone for political discussion is moderated by network characteristics in distinctive ways to predict levels of political engagement. The results and discussion address how the interplay between these aspects of political life may be both helpful and harmful for participation, and how the characteristics of strong network ties are particularly salient in a mobile communication context.

Before reviewing the relevant literature, some initial clarifications regarding scope and delimitation are in order. For the purposes of this study, mobile-based discussion refers to use of the mobile phone in general to discuss politics and public affairs, referring to all exchanges - voice calling, text messaging, or otherwise. This approach is grounded in previous research examining the political implications of mediated content patterns rather than technological features (Campbell \& Kwak, in press; Shah, Kwak, \& Holbert, 2001). Our parameters for what constitutes mobile communication exclude networked devices that are portable such as laptop computers, although these and other communication formats are accounted for in the analysis. As we argue below, there are distinctions between mobility and portability that contribute to important differences in network communication flows. The scope of this study is also delimited to strong, as opposed to weak, network ties (Granovetter, 1973). Although mobile communication is sometimes used to connect with new and weak ties (Boase \& Kobayashi, 2008; Wilken, 2011), it has become a primary resource for connecting with close personal ties, who have an especially important influence on the technology's use and consequences (Campbell \& Russo, 2003; Habuchi, 2005; Ling, 2004, 2008). On a broader level, "close tie relationships have theoretical importance because they are central in social influence and normative pressures (Burt, 1984:127)" (McPherson, Smith-Lovin, \& Brashears, 2006).

\section{Distinctive aspects of mobile communication}

Mobile communication technology is the fastest diffusing medium ever, yet "there are but scant offerings on the contribution of mobile communication to political life" (Gergen, 2008, p. 297). This contribution is evident in how the technology was prominently used for updates during the last U.S. presidential election, culminating in a record-breaking spike in text messaging on its final day (Aleo-Carreira, 2008; AT\&T, 2008). Mobile communication tends to serve as an added layer of communication (Ishii, 2006; Ling, 2008; Wellman et al., 2003), suggesting it may have implications for political life that extend beyond the use of other channels. Furthermore, this medium is distinct from others in the way it is characteristically person-to-person and more flexible. As Ling (2008) explains, "Instead of calling to a geographic location in the hope that our intended interlocutor is nearby (as with the landline system), we call or send messages directly to the individuals" (p. 160). Although also flexible, $\mathrm{CMC}$ is still constrained by the need for spaces with requisite 
infrastructure, even with portable computers (Castells, 2000). Portable devices are carried from place to place, whereas mobile devices afford communication during physical movement. Thus, mobile communication is possible virtually anytime and anywhere, allowing users to seamlessly weave network interactions into the rhythm of their daily affairs more easily (Ling, 2008).

Like CMC and the landline, face-to-face interaction is also less flexible than mobile communication in that it is place-based - even more so considering individuals must occupy shared space. Individuals must either make prior arrangements to talk in person or rely on the chance encounter. Mobile communication is also distinct from face-to-face interaction in that it affords a heightened degree of selectivity and control during interactions, particularly those that take place around copresent others. Oftentimes, copresent interactions are open to the possibility of others joining the conversation, whereas mobile-mediated exchanges tend to be exclusive and closed. As Ling (2008) explains, "[This] system of interaction is relatively closed to new insights" (p. 182). In other words, mobile communication is characteristically selective with regard to whom we are connected with as well as what those connections entail, a phenomenon Matsuda (2005) refers to as selective sociality.

Thus, mobile communication lowers the threshold for interaction with select others, while at the same time raises the threshold for engagement with individuals not part of targeted exchanges, suggesting both promise and peril for political life. On the one hand, mobile communication affords heightened flexibility for discussing politics and public affairs by allowing users to connect virtually anytime-anywhere. On the other hand, the selective sociality associated with mobile communication raises concerns among scholars that it can feed into network insularity, with individuals to turning inward socially and detaching from the political process (Gergen, 2008; Ling, 2008; Wilken, 2011). These concerns are bolstered by evidence that intensive network interaction through the mobile phone can lead to social cocooning for certain users (Habuchi, 2005).

Of course, "promoting active citizenship is a social, not a technological activity" (Hardy \& Scheufele, 2006, p. 1252), making aspects of whom one is connected with as important as the medium itself. For example, Wojcieszak (2009) reports a significant moderating effect for like-mindedness of strong ties, but not for weak ones, on associations between online and offline political participation. Considering this and research highlighting the influence of strong ties on mobile communication practices (Campbell \& Russo, 2003; Ling, 2008), we are interested in how characteristics of strong ties moderate the links between mobile-based discussion and political participation. Building up to this, we will first turn to literature on political discussion and new media to clarify expectations about the direct relationship between mobilebased discourse and participation.

\section{Political discussion, new media, and network characteristics}

Political talk is a fundamental building block of participatory democracy (Katz, 1994; Pan, Shen, Paek, \& Sun, 2006). While some regard it as a form of political 
participation (Delli Carpini, Cook, \& Jacobs, 2004), others recognize it as an analytic category in its own right that has a positive effect on other forms of involvement (Eveland \& Hively, 2009; Gastil, Deess, \& Weiser, 2002; Kwak et al., 2005; Lenart, 1994; McLeod, Scheufele, \& Moy, 1999; Wyatt, Katz, \& Kim, 2000). Talking about politics and public affairs helps citizens overcome uncertainty as they filter and make sense of the macrolevel political environment (Gastil \& Dillard, 1999; Pan et al., 2006). Accordingly, political talk also enhances the value of mass-mediated news and information (Scheufele, 2000, 2002).

As noted, much of the work on political talk has assumed it takes place in a face-to-face context. However, with the uptake of new media, scholars have begun to examine the links between political discourse online and its relationship to participation offline. This research reveals trends consistent with offline political talk, with positive direct relationships between discussion online and engagement offline (Hardy \& Scheufele, 2005, 2006; Johnson \& Kaye, 2003; Price \& Capella, 2002; Shah, Cho, Eveland, \& Kwak, 2005; Wyatt et al., 2000), and findings that discussion online complements and is complemented by other sources of news and information (Hardy \& Scheufele, 2005; Shah et al., 2005). In a recent study of mobile communication (Campbell \& Kwak, 2010) report a positive association between using the technology to discuss politics and public affairs (with anyone) and offline participation. As Hardy and Scheufele (2006) conclude, "The important role of interpersonal communication as a necessary condition for meaningful citizenship is relatively stable across media" (p. 1252, emphasis added). Considering the heightened flexibility of mobile communication discussed above, one can expect that it extends on the benefits of other platforms for political discourse when examining the direct relationship with political participation.

H1: Mobile-mediated discourse with strong ties will be positively associated with levels of political participation.

Discussion network characteristics, namely size and heterogeneity, can also have a significant effect on levels of participation. With regard to size, research consistently shows that members of larger discussion networks tend to be more politically engaged (Eveland \& Hively, 2009; Kwak et al., 2005; Mutz, 2002). Evidence suggests that larger networks serve as a more robust resource for deliberative discourse, political knowledge, and overcoming ambivalence (Huckfeldt, Mendez, \& Osborn, 2004; Moy \& Gastil, 2006). In addition, larger networks provide increased opportunities to encounter others who are politically active, which also helps boost participation (Eveland \& Hively, 2009). Because strong ties play such an important role in shaping mobile communication practices (Campbell \& Russo, 2003; Ling, 2008), their characteristics - in this case size — should have an important influence on whether the technology plays a constructive role in political life. Therefore, it is likely that benefits of using mobile technology for political discussion with strong ties are enhanced when one has a more robust personal communication network. 
H2: Network size will have a positive interactive effect on the association between mobile-based discussion and political participation.

Traditionally, political theory has favored the assumption that heterogeneity in discussion networks has a positive impact on citizenship (Arendt, 1968; Habermas, 1989). Indeed, several studies have linked it to increased participation, either directly or through enhanced political knowledge (Kwak et al., 2005; Leighley, 1990; McLeod et al., 1999; Scheufele, Hardy, Brossard, Waismel-Monor, \& Nisbet, 2006; Scheufele, Nisbet, Brossard, \& Nisbet, 2004). However, findings for heterogeneity have not been consistent. Notably, Mutz (2002) found that individuals whose discussion networks involve greater disagreement have lower levels of political participation, a finding that was recently supported in a study by Eveland and Hively (2009). It is likely that divergent findings for heterogeneity are partially attributable to how it is conceptualized and measured (Eveland \& Hively, 2009). Although some scholars have treated heterogeneity as exposure to differing political views (Mutz, 2002), others have included measures for demographic differences as well (Kwak et al., 2005; McLeod, Sotirovic, \& Holbert, 1998; Scheufele et al., 2004). Considering the variation surrounding this concept, it is worth specifying that for the purpose of this study, the term heterogeneity is used to characterize the relative number of non-like-minded individuals in one's network of close personal ties, which is similar to Mutz's (2002) treatment in that demographic differences are not included in the concept.

Mutz attributes negative effects of heterogeneity on participation to intra- and interpersonal conflict stemming from dissonant discourse within the networks. On the intrapersonal level, disagreement in discussion networks can lead to political ambivalence. On the interpersonal level, individuals in diverse discussion networks are thought to be less likely to participate in politics because they prefer to avoid conflict with fellow network members. As is the case with size, we anticipate this characteristic to moderate the relationship between mobile-based discussion and participation. Drawing from related studies (Eveland \& Hively, 2009; Mutz, 2002), we predict that:

H3: Network heterogeneity will have a negative interactive effect on the association between mobile-based discussion and political participation.

The hypotheses advanced so far examine the two-way interactions among mobile-mediated discourse and each of the network characteristics when considered separately. In these cases, we have hypothesized the extension of trends observed with other formats for political discussion. However, as discussed below, there are reasons to expect the three-way interaction between mobile communication and network characteristics might result in distinctive trends. Related research shows that creating three-way interaction terms can be a useful approach for more nuanced understanding of how political discussion, network characteristics, and media use intersect in shaping political life (Feldman \& Price, 2008; Kwak et al., 2005). Of 
particular relevance to this study, Kwak et al. (2005) found a three-way interaction between political talk, network size, and network heterogeneity in predicting political participation. Their results indicate that individuals tend to be more participatory when discussing politics with a small number of others who are like them.

On the surface, Kwak et al.'s (2005) finding may seem to provide grounds for anticipating that political participation increases with mobile-mediated discourse in small networks of like-minded individuals. However, it is important to recognize key differences between the two studies. Like most of the previous research, Kwak et al. (2005) assessed overall levels of political discussion, without accounting for communication channel, whereas this study examines discussion that takes place via mobile communication. In addition, the two studies differ dramatically in their treatment of network characteristics. Discussion partners in their study include both strong and weak ties combined, while we are interested in mobile communication among close personal ties. Finally, Kwak et al. (2005) combined both ideological and demographic characteristics in their measure of network heterogeneity, whereas we focus only on the extent to which network ties are like-minded in their political views.

In fact, scholars have become increasingly concerned that intensive mobile communication in small, like-minded networks of close ties may hinder political involvement and other aspects of public life (Gergen, 2008; Ling, 2008; Wilken, 2011). Gergen (2003) argues many people now live in floating worlds of friends and family members, which sustain their own realities, values, and logics through mediated contact throughout their daily lives. The possibility of perpetual contact, where individuals maintain a constant flow of interaction while apart or on the move, has only recently become fully realized through the anytime-anywhere affordances of mobile communication (Katz \& Aakhus, 2002). Similar to Sunstein's (2001) theory that the Internet can serve as an echo chamber of news and information, Gergen (2008) warns that perpetual contact among network ties can be harmful for civil society when they become overly consumed with their own perspectives and interests. Sunstein's concern is that echo chambers of mass-mediated news and information can lead to political polarization, whereas Gergen argues political withdrawal can occur when these chambers form at the interpersonal level. Mobile communication plays an integral role in their formation, as do the characteristics of close personal networks, particularly when they are small and like-minded. Gergen argues that continual mobile contact in these types of networks, which he characterizes as monadic clusters, leave little room for deliberative dialog as individuals affirm and reaffirm each others' shared views and interests in circular fashion, leading to withdrawal from broader realms of social order as their attention is drawn inward.

Because there are competing lines of reasoning on how frequency of mobile discourse, network size, and like-mindedness intersect to predict political participation, we advance the following research question, rather than a hypothesis, about the three-way interaction effects. 
RQ: How does the interplay between the two network characteristics moderate the relationship between mobile-based discussion and political participation?

\section{Method}

\section{Sample}

Data for this study come from a national mail survey that was conducted during the 2008 U.S. presidential campaign. The data collection was conducted by the research firm Synovate. A massive number of people were contacted via mail and asked to express their willingness to participate in mail, telephone, or online surveys, and if so, to provide basic demographic information. A balanced sample was then drawn from among the more than 500,000 people who agreed to participate in the prerecruited "mail panel."

To ensure representativeness, the sample for the current survey was drawn to reflect demographic distributions within the five census divisions of household income, population density, panel member's age, gender, and region. This stratified quota sampling method was used to select 2,218 mail survey respondents. There were 66 undeliverable surveys and 1,018 usable responses were received. Thus the response rate was $47.3 \%$. This stratified quota sampling method differs markedly from more conventional probability sample procedures yet produces highly comparable data (Putnam, 2000; Putnam \& Yonish, 1999). Because this study examines the role of mobile-mediated political discussion within one's close network, the analyses reported in this study were conducted among 943 respondents whose strong-tie network consisted of at least two people.

Demographic characteristics of the current sample resemble the profiles of the national population figures reported in U.S. Census Bureau's 2007 American Community Survey (ACS), with respect to education attainment (the median education level for those 25 or older in both data sets is some college), household income (the median in the ACS and this study is \$50,000-74,999 and \$50,000-59,999, respectively), and age (the median age for those 18 or older in the ASC and this study is $45-54$ and 53, respectively). However, there is a greater percentage of male respondents in the sample $(59.7 \%)$ than in the ACS (48.6\%).

\section{Criterion variable: Political participation}

Respondents were asked about four types of involvement in traditional forms of political participation: attending a political meeting, rally, or speech; working for a candidate or a party; contacting a public official or a political party; and contributing money to a candidate or a political party (McLeod et al., 1999; Milbraith \& Goel, 1971; Xenos \& Moy, 2007). Respondents reported the frequency of involvement in each type of participation in the past month on a 7-point scale, ranging from none in the last month to everyday. The responses were summed to form an additive index $(M=1.20, S D=.43$, Cronbach $\alpha=.68)$. 


\section{Network characteristics and political mobile phone use}

Size

Respondents were asked to write in the number of how many people they had in their network of strong personal ties, which were defined as "those who you feel very close to and with whom you are frequently in contact to discuss various things, including your personal issues and feelings" $(M=8.97, S D=8.20) .{ }^{1}$ Those reporting more than 20 were grouped together, which is consistent with previous research (Kwak et al., 2005). Responses that were missing/invalid $(n=44)$ or containing no strong ties $(n=25)$ were removed from the analysis.

\section{Heterogeneity}

Two items were used to tap the degree of heterogeneity of one's strong ties. Respondents were asked to report how many of the people in their network of strong personal ties shared their political views and how many supported the same presidential candidate as the respondent. The responses were recorded on a 5-point scale, consisting of none, only some, about half, most of them, and all. The responses were reverse coded and added to form an index $(M=2.69, S D=.99$, interitem $r=.72)$.

\section{Mobile phone use for political discussion}

To tap respondents' political use of the mobile phone with their close ties, an item that asked about the frequency of mobile communication for discussing politics and public affairs was used. An 8-point response scale, ranging from none in the last month to several times a day, was used $(M=2.65, S D=1.83)$. Those who reported not using a mobile phone were treated as zero frequency.

\section{Control variables}

As control variables, this study included age, gender, education, household income, political interest, newspaper use, and television news use (local and national programs), which have been found to influence the criterion variables (Jeffres, Atkin, \& Neuendorf, 2002; Jennings \& Zeitner, 2003; Shah et al., 2001, 2005). In addition, the study controlled for other modes of political discourse, including political talk in general and CMC-based discussion. General political talk was measured with an additive index of the following two items with a 7-point scale ranging from none in the last month to every day; "Talked about politics with friends" and "Talked about politics with family" ( $M=3.23, S D=1.54$, Cronbach $\alpha=.78)$. CMC-based discussion was assessed with the following item, which had an 8-point response option ranging from none in last month to several times a day: "Discussed politics on a Web site or over e-mail" ( $M=1.49, S D=1.17)$. To measure political interest, respondents were asked to state how much they agreed with the following statement, "I am very interested in politics," on a 6-point scale, ranging from definitely disagree to definitely agree $(M=3.49, S D=1.63)$. For mass media use variables, respondents were separately asked, using a 5-point scale, about how often in the past month 
they used daily newspapers $(M=3.59, S D=1.42)$, national nightly news, and local television news programs. The two television items were combined as an index $(M=3.58, S D=1.15$, Cronbach $\alpha=.56)$.

\section{Interaction terms}

To carry out analyses corresponding to $\mathrm{H} 2, \mathrm{H} 3$, and the research question, this study created interaction terms between mobile-mediated discourse and each of the two measures of network characteristics (i.e., size and heterogeneity). ${ }^{2}$ In addition, to investigate the RQ, this study created a three-way interaction term among political mobile phone use with close ties and the two network variables. To reduce potential problems with multicollinearity between interaction terms and their components, all the component variables were standardized before the formation of the interaction terms (Cronbach, 1987; Jaccard, Turrisi, \& Wan, 1990; Kwak, 1999).

\section{Results}

Findings concerning $\mathrm{H} 1$ are presented in Table 1. A total of four regression analyses were run for political participation. The first column in Table 1 is from a regression analysis in which control variables and use of the mobile for political discussion with strong ties were examined, and in the other three columns general political talk and/or computer-mediated political discussion measures were incorporated as additional control variables. The latter analyses were conducted to see whether the relationship between mobile-mediated discussion and political participation changed when other forms of political discussion are considered.

As shown in Table 1, control variables, as a block, accounted for a significant amount of variance in the criterion variable ( $R^{2}$ is around $\left.13 \%\right)$. After the control, mobile-based political discussion was found to be a meaningful predictor of political participation (first column), however, this relationship is fairly moderate in strength $(\beta=.13, p<.01)$. The mobile communication measure remained significant, when general political talk ( $\beta=.10, p<.01$; second column) or CMC-based discussion $(\beta=.08, p<.05)$ was also included in the respective analysis. However, as shown in the last column of Table 1, when all three discussion variables were simultaneously considered, the relationship between mobile phone use and political participation became weaker and marginal in significance $(\beta=.06, p<.09)$. In fact, in the regression model, CMC-based political discussion emerged as the strongest $(\beta=.22$, $p<.01$ ), while general political talk was also found to be marginally significant $(\beta=.07, p<.06)$.

While the findings in Table 1 suggest that mobile-mediated political dialog could be a positive factor, the analysis reported in Table 2 examined a possibility that the role of mobile-mediated political discussion might be strengthened or weakened depending on the nature of one's network of strong ties. As shown in Table 2 and expected in this study $(\mathrm{H} 2)$, the interaction term between mobile phone use and 
Table 1 Predictors of Political Participation, Direct Relationships

\begin{tabular}{|c|c|c|c|c|c|c|c|c|}
\hline & \multicolumn{2}{|c|}{$\begin{array}{l}\text { Other Formats } \\
\text { Not Controlled }\end{array}$} & \multicolumn{2}{|c|}{$\begin{array}{c}\text { General Talk } \\
\text { Controlled }\end{array}$} & \multicolumn{2}{|c|}{$\begin{array}{c}\text { CMC } \\
\text { Discussion } \\
\text { Controlled }\end{array}$} & \multicolumn{2}{|c|}{$\begin{array}{c}\text { General and } \\
\text { CMC } \\
\text { Controlled }\end{array}$} \\
\hline & $\beta$ & $t$ Value & $\beta$ & $t$ Value & $\beta$ & $t$ Value & $\beta$ & $t$ Value \\
\hline \multicolumn{9}{|l|}{ Control variables } \\
\hline Age & .05 & 1.52 & $.06^{\#}$ & 1.66 & $.08^{*}$ & 2.25 & $.08^{*}$ & 2.39 \\
\hline Gender (high: female) & $-.70^{*}$ & -2.17 & $-.07^{\#}$ & -2.14 & $-.07^{*}$ & -2.03 & $-.06^{*}$ & -1.98 \\
\hline Education & $.17^{* *}$ & 4.98 & $.16^{* *}$ & 4.78 & $.15^{* *}$ & 4.29 & $.14^{* *}$ & 4.17 \\
\hline Household income & -.05 & 1.56 & $-.07^{\#}$ & -1.92 & -.078 & -1.58 & $-.06^{\#}$ & -1.80 \\
\hline Political interest & $.21^{* *}$ & 6.14 & $.18^{* *}$ & 4.91 & $.18^{* *}$ & 5.14 & $.15^{* *}$ & 4.26 \\
\hline Newspaper news use & $.10^{* *}$ & 3.01 & $.10^{* *}$ & 2.81 & $.09^{* *}$ & 2.59 & $.08^{*}$ & 2.38 \\
\hline Television news use & .02 & .54 & .02 & .44 & .04 & 1.11 & .04 & 1.05 \\
\hline$R^{2}(\%)$ & \multicolumn{2}{|c|}{13.1} & \multicolumn{2}{|c|}{13.3} & \multicolumn{2}{|c|}{13.3} & \multicolumn{2}{|c|}{13.5} \\
\hline \multicolumn{9}{|l|}{ Mobile phone use } \\
\hline Political discussion & $.13^{* *}$ & 3.83 & $.10^{* *}$ & 2.73 & $.08^{*}$ & 2.36 & $.06^{\#}$ & 1.71 \\
\hline Inc. $R^{2}(\%)$ & \multicolumn{2}{|c|}{1.5} & \multicolumn{2}{|c|}{1.6} & \multicolumn{2}{|c|}{1.3} & \multicolumn{2}{|c|}{1.4} \\
\hline \multicolumn{9}{|l|}{ Other discussion variables } \\
\hline General political talk & & & $.11^{* *}$ & 2.73 & & & .07 & 1.93 \\
\hline CMC-based discussion & & & \multirow{2}{*}{\multicolumn{2}{|c|}{.8}} & $.23^{* *}$ & 6.83 & $.22^{* *}$ & 6.43 \\
\hline Inc. $R^{2}(\%)$ & & & & & \multicolumn{2}{|c|}{4.5} & \multicolumn{2}{|c|}{4.9} \\
\hline Total $R^{2}(\%)$ & \multicolumn{2}{|c|}{14.6} & \multicolumn{2}{|c|}{15.6} & \multicolumn{2}{|c|}{19.2} & \multicolumn{2}{|c|}{19.8} \\
\hline$N$ & \multicolumn{2}{|c|}{853} & \multicolumn{2}{|c|}{839} & \multicolumn{2}{|c|}{841} & \multicolumn{2}{|c|}{827} \\
\hline
\end{tabular}

Note: $\mathrm{CMC}=$ computer-mediated communication. Entries are standardized final regression coefficients.

${ }^{\#} p<.10 ;{ }^{*} p<.05 ; * * p<.01$.

network size was found to be significant, and like the direct relationship moderate in strength $(\beta=.10, p<.01)$. This significant interaction indicates that the positive relationship between political use of the mobile phone with close others and political participation tends to be greater among those whose close personal network is greater in size. However, the interaction of the mobile communication measure and network heterogeneity was not significant, which thus failed to support $\mathrm{H} 3$.

The significant interactive relationship is plotted in Figure 1. As shown in this figure, for those whose network size is greater, more frequent use of the mobile phone with strong ties for discussing politics and public affairs is associated with an increase in political participation. However, for those whose strong-tie network consists of a smaller number of people, the positive relationship is not observed. Instead, frequent use of the mobile phone for political discussion within a small network does not appear to make individuals more participatory.

The three-way interaction term analyzed in Table 3 attempts to understand the role of mobile-mediated political discourse with the influence of network size 
Table 2 Two-Way Interactive Relationships Between Mobile-Mediated Political Discussion and Network Characteristics $(N=823)$

\begin{tabular}{lcc}
\hline & \multicolumn{2}{c}{ Political Participation } \\
\cline { 2 - 3 } & $\beta$ & $t$ Value \\
\hline Prior blocks $\left(R^{2}, \%\right)$ & & 20.0 \\
Mobile-mediated political discussion & $.10^{* *}$ & 3.06 \\
$\quad \times$ Network size & -.03 & -.89 \\
$\times$ Heterogeneity & & \\
\hline
\end{tabular}

Notes: Prior blocks include age, gender, education, household income, political interest, newspaper news use, television news use, general political talk, CMC-based political discussion, mobile-mediated political discussion, size of close network, and heterogeneity of close network. Entries are standardized regression coefficients after controlling for the prior blocks.

${ }^{* *} p<.01$.

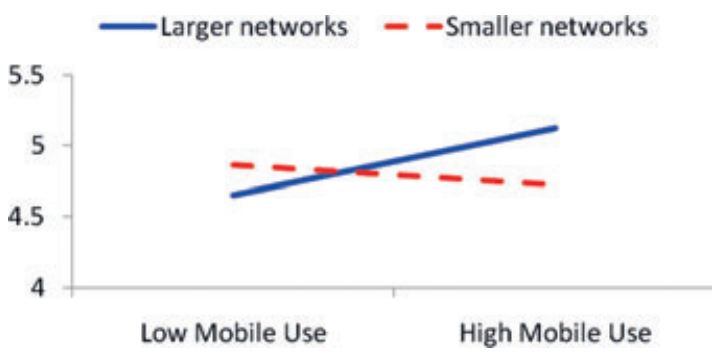

Figure 1 Predicting political participation with mobile-mediated discourse $\times$ network size.

and heterogeneity simultaneously considered. As shown in Table 3, the three-way interaction term was found to be significant $(\beta=-.09, p<.01)$. This negative three-way interaction suggests that the patterns of the interplay between mobile phone use and heterogeneity of strong ties in accounting for political participation vary across different sizes of one's network of strong ties. These three-way interactive relationships are plotted in Figure 2.

As shown in Figure 2, in explaining political participation the interplay between mobile phone use and network heterogeneity demonstrates markedly different patterns between networks of different sizes. When one's network consists of a larger number of close ties (see the top panel of Figure 2), the mobile communication variable tends to have a positive contribution when mobile-mediated political discussion occurs within a more homogeneous network of strong ties (see the dotted line), whereas participation levels are fairly flat with mobile communication in more heterogeneous networks that are large (see the solid line). However, when the size of the strong ties is smaller (see the bottom panel of Figure 2), the positive interplay of mobile phone use and network homogeneity completely disappears. If anything, the findings suggest that mobile-based political discussion among a small number of 
Table 3 Three-Way Interactive Relationships Among Mobile-Mediated Political Discussion, Heterogeneity, and Size $(N=810)$

\begin{tabular}{|c|c|c|}
\hline & \multicolumn{2}{|c|}{ Political Participation } \\
\hline & $\beta$ & $t$ Value \\
\hline $\begin{array}{l}\text { Prior blocks }\left(R^{2}, \%\right) \\
\text { Interaction term }\end{array}$ & \multicolumn{2}{|c|}{20.9} \\
\hline $\begin{array}{l}\text { Mobile-mediated political discussion } \times \text { network } \\
\text { heterogeneity } \times \text { network size }\end{array}$ & $-.09^{* *}$ & -2.68 \\
\hline
\end{tabular}

Notes: Prior blocks include age, gender, education, household income, political interest, newspaper news use, television news use, general political discussion, CMC-based political discussion, mobile-mediated political discussion, size of close network, and heterogeneity of close network, mobile-mediated political discussion $\times$ size of close network, mobilemediated political discussion $\times$ heterogeneity of close network, and heterogeneity of close network $\times$ size of close network. Entry is standardized regression coefficient after controlling for the prior blocks.

${ }^{* *} p<.01$.
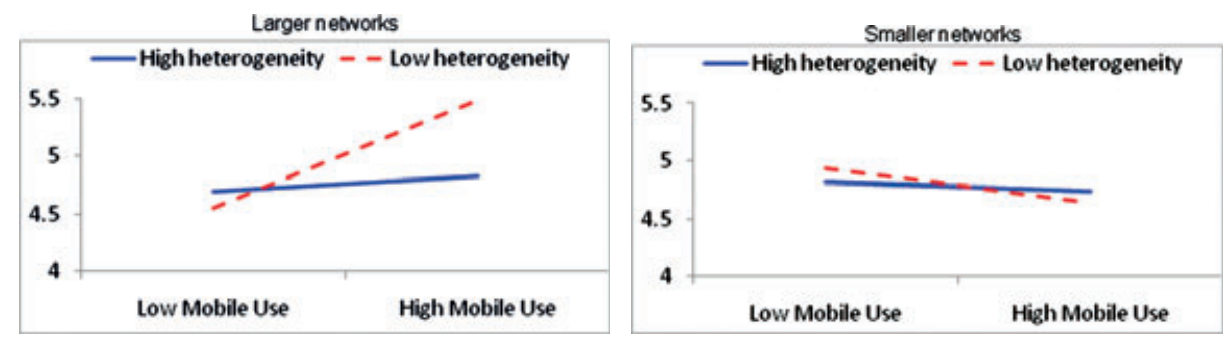

Figure 2 Predicting political participation with mobile-mediated discourse $\times$ network size $\times$ network heterogeneity.

strong ties with mutually affirming political views may be associated with political demobilization (see the dotted line).

\section{Discussion}

We anticipated that mobile communication-voice- or text-based-for political discussion with strong network ties would be directly related to increased political participation, but that this relationship would manifest differently through interactive effects with network size and heterogeneity. Tests for the direct relationship between mobile-based discussion and participation offer preliminary evidence that mobile communication has become a meaningful new platform for political discourse which extends on benefits of political talk in other contexts. Patterns in cross-sectional analysis are not sufficient for causal inferences, however, there are theoretical 


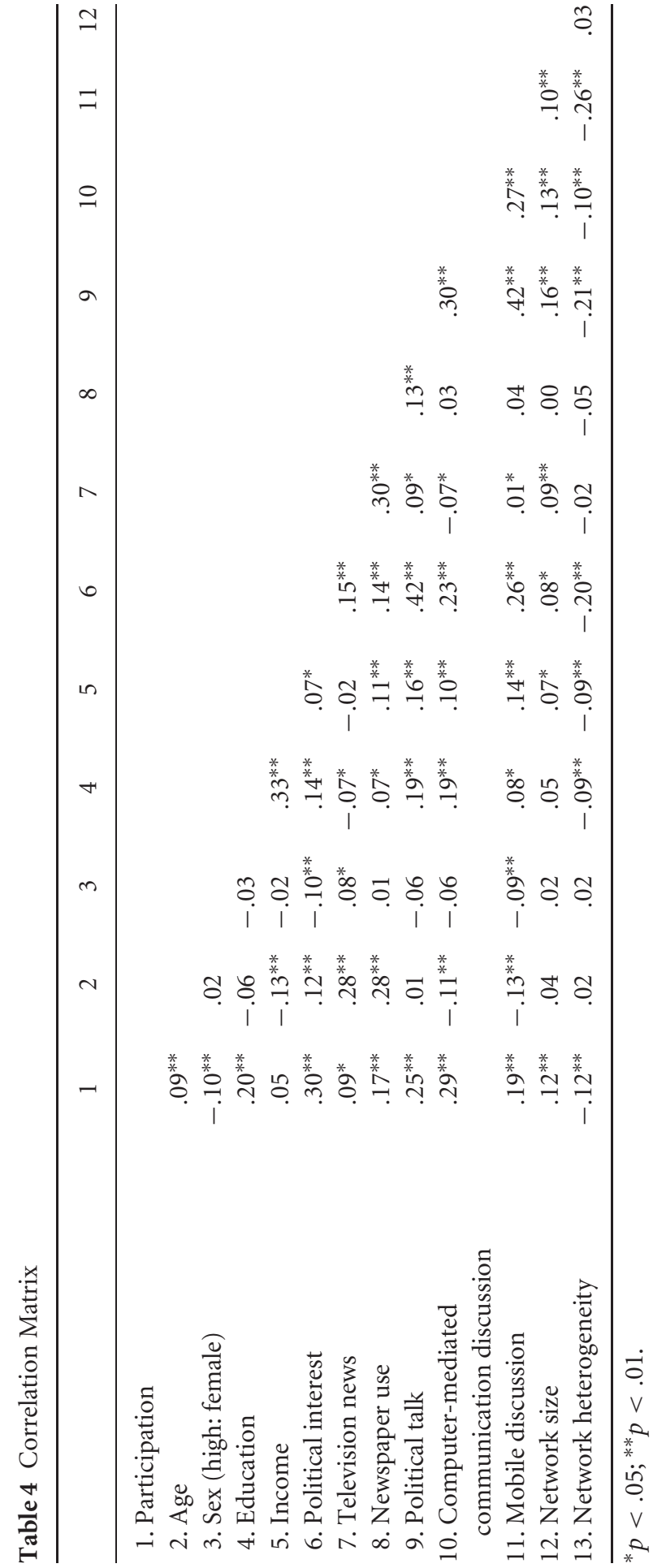


grounds for hypothesizing this is a likely effect, considering a similar effect has consistently been found for other channels (Hardy \& Scheufele, 2006).

Although this positive trend for mobile phone use among strong ties is interesting, there are also theoretical grounds for expecting that its role in political life is shaped by the characteristics of these ties, including their size and level of agreement. The significant two-way interaction between mobile communication and network size illustrates that participation increases with frequent mobile-based discourse in larger networks, whereas this trend is reversed for smaller networks (Figure 1). As with the direct relationship, these associations are consistent with patterns found in previous research on political talk in general (Kwak et al., 2005). Furthermore, they extend above and beyond other modes of mediated and unmediated discourse, supporting our overarching position that core network characteristics have an important influence on the role of mobile communication as a political resource.

As the significant three-way interaction reveals, whether and the extent to which the benefits of network size are harnessed are also dependent on the level of agreement among those ties. The top of Figure 2 shows that participation levels rise with increased mobile discourse in larger networks only when those ties are like-minded. This nuance helps clarify the complex relationship between use of the technology for political sense making and other forms of political involvement. Mutz (2002) argues that discussing politics (broadly speaking) with others who agree mitigates problems of ambivalence and social conflict that can hinder political action. This study offers evidence that when this political environment is constructed through mobile communication, having a relatively large network is an important condition for the benefits of homogeneity to play out in a constructive way. Conceivably, mobile communication with a large number of close and trusted discussion partners helps boost the salience and personal relevance of supporting views, creating a discussion environment that is not only safe, but also robust and therefore more meaningful. Because it involves frequent mobile communication, this environment extends beyond traditional boundaries of space and time, allowing individuals to flexibly engage in political exchanges while carrying on with their daily life activities and movements. In contrast, the bottom of Figure 2 suggests that like-mindedness is not necessarily helpful for those engaged in mobile-based discourse with very few strong ties. These individuals are still connected with others they are close to and who support their views, yet there is somewhat of a downward trend in their level of political participation.

The more negative trend for increased mobile-based discussion in networks that are both small and like-minded opens up theoretical considerations about how these conditions may be an indication of social privatism. In his critique of Putnam's (2000) Bowling Alone, Fischer (2005) argues that observed trends for the erosion of civic life in American society are not as attributable to individualistic retreat as they are to withdrawal "into a more private world of family, work, and friends - a story of greater, but still social, privatism" (p.6, emphasis in original text). This form of 
social withdrawal resonates with propositions that intensive mobile communication among a small number of close friends and family members can lead to insularity (Habuchi, 2005; Ling, 2008), especially Gergen's (2008) argument about so-called monadic clusters of small and like-minded network ties. The thinking here is that continual anytime-anywhere contact in these small, tightly knit enclaves constrains political dialog and participation in broader levels of civil society. These individuals are engaged in what Gergen (2008) refers to as circular affirmation, which reinforces boundaries on their worldview as they focus their attention inward.

Findings from this study provide empirical support for the argument that this dynamic may be somewhat constraining in small networks highly connected through the mobile phone, yet supportive in networks containing a large number of close personal ties. From a social capital perspective, engagement with a number of network ties contributes to social trust and the desire to make contributions for mutual benefit. When these network ties share views and interests, participating in the political process is, in a sense, making a positive contribution to the network as well as society. Being less socially connected on the personal level can have the exact opposite effect by decreasing one's motivation to participate. Although these premises apply to social interaction broadly speaking, the findings from this study offer evidence that mobile communication plays a distinctive role in not only strengthening core ties (per Ling, 2008), but also in strengthening their influence on political life, for good or bad.

Collectively, the findings from this study shed new light on the structure of the relationships between mobile communication, social networks, and political life. However, it is important to recognize some limitations in scope and method that open new avenues for future investigation. Because it directly extends previous research on political talk, the scope of this study narrowly focused on mobile phone use for discourse about politics and public affairs. It is possible that use of the technology for other purposes would yield disparate results. Therefore, future research should examine other usage patterns, including relational exchanges and instrumental coordination (Ling, 2004). Future investigations should also account for the use of various technological features. Mobile technology is becoming increasingly multimedia, supporting not only interpersonal discourse, but also the exchange of photographs, location-based information, and mass communication content through the Internet. As Koskinen (2008) argues, the use of these and other multimodal aspects of the technology may have significant ramifications for civic society. Future research should account for specific features used during mobile-mediated exchanges, such as voice calling, text messaging, instant messaging, multimedia messaging, and Web-based interactions.

Because the data are cross-sectional in nature, it is difficult to say with certainty whether mobile communication influences involvement in political life, or whether the arrow of causality points in the other direction. Other contexts of political discourse have been found to have a positive influence on political involvement, providing some theoretical foundation for presuming mobile-mediated discourse 
has a similar effect. However, this presumption needs to be verified through followup investigations using experimental and/or multiwave panel approaches. These undertakings will not only allow researchers to examine effects on political life, but also the causal relationships between the use of mobile technology and social network characteristics as well. For purposes of developing a theoretical model, it will be useful to establish the direction of causality among all of these components.

Finally, future investigations should examine the political implications of mobile technology for different user segments. One way of differentiating subpopulations is to categorize according to age or lifecycle groupings. Age plays an important role in how people conceptualize and use new media and the extent to which they are politically engaged. Drawing from CMC research (Shah et al., 2001), one could hypothesize that effects of mobile communication on political life are more profound for younger users than those who are older and more accustomed to other channels for political discussion.

\section{Concluding remarks}

Considering Putnam's $(1995,2000)$ dire account of declining political participation in the United States, followed by the countertrend of increased voter turnout in subsequent national elections, it is important for scholars to examine recent changes in civil society and how its members are engaged in political discourse. Although it would be premature to assert that the rise of mobile communication has helped boost political enthusiasm and voter turnout, the findings from this study provide some cause for optimism about the role the technology plays in political life. However, such optimism must be qualified with recognition that the possible benefits of mobile-mediated discourse hinge on the size and heterogeneity of one's network ties, illustrating the importance of accounting for these and other aspects of social context in future research.

\section{Notes}

1 It is worth clarifying that network characteristics examined in this study refer to structural features of one's close network. This study is interested in the interplay between these structural features and mobile-based political discourse within the close network, which are treated conceptually distinct. Another approach to understanding the role of mobile-based political discussion in close networks would be to incorporate and examine subcomponents of the close network, such as structural features of one's mobile-specific discussion network, rather than the network more broadly.

2 For all figures, the high or low group for each variable refers to those whose value for a respective variable was one standard deviation higher or lower than the mean. For variables that were not components of interaction terms, mean values were assigned. For gender, female was assigned. All coefficients required to compute estimates came from a respective regression equation that included control variables, media use measures, all three discussion variables, network size, heterogeneity, lower-order interaction terms, if applicable, and the interaction analyzed. 


\section{References}

Aleo-Carreira, C. (2008). Did social media decide the U.S. presidential election in Obama's favor? (Online exclusive). The Industry Standard. Retrieved from http://www.thestandard.com/news/2008/11/05/did-social-media-decide-u-spresidential-election-obamas-favor.

Arendt, H. (1968). Truth and politics. In H. Arendt (Ed.), Between past and future: Eight exercises in political thought (pp. 227-264). New York, NY: Viking Press.

AT\&T. (2008). AT\&T reports largest text messaging spike in company history on election night (Press release). Retrieved from http://www.att.com/gen/press-room?pid=4800\& $\mathrm{cdvn}=$ news\&newsarticleid $=26287$.

Boase, J., \& Kobayashi, T. (2008). Kei-Tying teens: Using mobile phone e-mail to bond, bridge, and break with social ties - a study of Japanese adolescents. International Journal of Human-Computer Studies, 66(12), 930-943.

Campbell, S. W., \& Kwak, J. (2010). Mobile communication and civic life: Linking patterns of use to civic and political involvement. Journal of Communication, 60(3), 536-555.

Campbell, S. W., \& Russo, T. C. (2003). The social construction of mobile telephony: An application of the social influence model to perceptions and uses of mobile phones within personal communication networks. Communication Monographs, 70(4), 317-334.

Castells, M. (2000). The rise of the network society (2nd ed.). Oxford, England: Blackwell.

Cronbach, L. J. (1987). Statistical tests for moderator variables: Flaws in analyses recently proposed. Psychological Bulletin, 102(3), 414-417.

Delli Carpini, M. X., Cook, F. L., \& Jacobs, L. R. (2004). Public deliberation, discursive participation, and citizen engagement: A review of the empirical literature. Annual Review of Political Science, 7, 315-344.

Eveland, W. P., \& Hively, M. H. (2009). Political discussion frequency, network size, and "heterogeneity" of discussion as predictors of political knowledge and participation. Journal of Communication, 59(2), 205-224.

Feldman, L., \& Price, V. (2008). Confusion or enlightenment? How exposure to disagreement moderates the effects of political discussion and media use on candidate knowledge. Communication Research, 35(1), 61-87.

Fischer, C. S. (2005). Bowling Alone: What's the score? Social Networks, 27(2), 155-167.

Gastil, J., Deess, E. P., \& Weiser, P. (2002). Civic awakening in the jury room: A test of the connection between jury deliberation and political participation. Journal of Politics, 64(2), 585-595.

Gastil, J., \& Dillard, J. P. (1999). Increasing political sophistication through public deliberation. Political Communication, 16(1), 3-23.

Gergen, K. J. (2003). Self and community in the new floating worlds. In K. Nyiri (Ed.), Mobile democracy: Essays on society, self, and politics (pp. 103-114). Vienna: Passagen Verlag.

Gergen, K. J. (2008). Mobile communication and the transformation of the democratic process. In J. Katz (Ed.), Handbook of mobile communication studies (pp. 297-310). Cambridge, MA: MIT Press.

Granovetter, M. S. (1973). The strength of weak ties. American Journal of Sociology, 78(6), $1360-1380$.

Habermas, J. (1989). The structural transformation of the public sphere: An inquiry into a category of bourgeois society. Cambridge, MA: MIT Press. 
Habuchi, I. (2005). Accelerating reflexivity. In M. Ito, D. Okabe, \& M. Matsuda (Eds.), Personal, portable, pedestrian: Mobile phones in Japanese life (pp. 165-182). Cambridge, MA: MIT Press.

Hardy, B. W., \& Scheufele, D. A. (2005). Examining differential gains from Internet use: Comparing the moderating role of talk and online interactions. Journal of Communication, 55(1), 71-84.

Hardy, B. W., \& Scheufele, D. A. (2006). New media and democratic citizenship. Encyclopedia of Digital Government, III, 1250-1254.

Huckfeldt, R., Mendez, J. M., \& Osborn, T. (2004). Disagreement, ambivalence and engagement: The political consequences of heterogeneous networks. Political Psychology, 25(1), 65-95.

Ishii, K. (2006). Implications of mobility: The uses of personal communication media in everyday life. Journal of Communication, 56(2), 346-365.

Jaccard, J., Turrisi, R., \& Wan, C. K. (1990). Interaction effects in multiple regression. Newbury Park, CA: Sage.

Jeffres, L. W., Atkin, D., \& Neuendorf, K. A. (2002). A model linking community activity and communication with political attitudes and involvement in neighborhoods. Political Communication, 19(4), 387-421.

Jennings, M. K., \& Zeitner, V. (2003). Internet use and civic engagement: A longitudinal analysis. Public Opinion Quarterly, 67(3), 311-334.

Johnson, T. J., \& Kaye, B. K. (2003). A boost or bust for democracy? How the web influenced political attitudes and behaviors in the 1996 and 2000 presidential elections. The Harvard International Journal of Press/Politics, 8(3), 9-34.

Katz, E. (1994). Introduction: The state of the art. In T. Glasser \& C. Salmon (Eds.), Public opinion and the communication of consent (pp. xiv-xxxiv). New York, NY: Guilford.

Katz, J. E., \& Aakhus, M. A. (Eds.). (2002). Perpetual contact: Mobile communication, private talk, public performance. Cambridge, England: Cambridge University Press.

Koskinen, I. (2008). Mobile multimedia: Uses and social consequences. In J. Katz (Ed.), Handbook of mobile communication studies (pp. 241-255). Cambridge, MA: MIT Press.

Kwak, N. (1999). Revisiting the knowledge gap hypothesis: Education, motivation, and media use. Communication Research, 26(4), 385-413.

Kwak, N., Williams, A., Wang, X., \& Lee, H. (2005). Talking politics and engaging politics: An examination of the interactive relationships between structural features of political talk and discussion engagement. Communication Research, 32(1), 87-111.

Leighley, J. A. (1990). Social interaction and contextual influences on participation. American Politics Quarterly, 18(4), 459-475.

Lenart, S. (1994). Shaping political attitudes: The impact of interpersonal communication and mass media. Thousand Oaks, CA: Sage.

Ling, R. (2004). The mobile connection: The cell phone's impact on society. San Francisco, CA: Morgan Kaufman.

Ling, R. (2008). New tech, new ties: How mobile communication is reshaping social cohesion. Cambridge, MA: MIT Press.

Matsuda, M. (2005). Mobile communication and selective sociality. In M. Ito, D. Okabe, \& M. Matsuda (Eds.), Personal, portable, pedestrian: Mobile phones in Japanese life (pp. 123-142). Cambridge, MA: MIT Press. 
McLeod, J. M., Scheufele, D. A., \& Moy, P. (1999). Community, communication, and participation: The role of mass media and interpersonal discussion in local political participation. Political Communication, 16(3), 315-336.

McLeod, J. M., Sotirovic, M., \& Holbert, R. L. (1998). Values as sociotropic judgments influencing communication patterns. Communication Research, 25(5), 453-485.

McPherson, M., Smith-Lovin, L., \& Brashears, M. (2006). Social isolation in America: Changes in core discussion networks over two decades. American Sociological Review, 71(3), 353-375.

Milbraith, L., \& Goel, M. (1971). Political participation (2nd ed.). Chicago, IL: Rand McNally.

Moy, P., \& Gastil, J. (2006). Predicting deliberative conversation: The impact of discussion networks, media use, and political cognitions. Political Communication, 23(4), 443-460.

Mutz, D. C. (2002). The consequences of cross-cutting networks for political participation. American Journal of Political Science, 46(4), 838-855.

Pan, Z., Shen, L., Paek, H.-J., \& Sun, Y. (2006). Mobilizing political talk in a presidential campaign: An examination of campaign effects in a deliberative framework. Communication Research, 33(5), 315-345.

Price, V., \& Capella, J. H. (2002). Online deliberation and its influence: The electronic dialogue project in Campaign 2000. IT \& Society, 1(1), 303-329. Retrieved from http://www.stanford.edu/group/siqss/itandsociety/v01i01/v01i01a20.pdf.

Putnam, R. D. (1995). Bowling alone: America's declining social capital. Journal of Democracy, 6(1), 65-78.

Putnam, R. D. (2000). Bowling alone: The collapse and revival of American community. New York, NY: Simon \& Schuster.

Putnam, R. D., \& Yonish, S. (1999, May). How important are random samples? Some surprising new evidence. Paper presented to the annual meeting of the American Association of Public Opinion Research, St. Petersburg, FL.

Scheufele, D. A. (2000). Talk or conversation? Dimensions of interpersonal discussion and their implications for participatory democracy. Journalism and Mass Communication Quarterly, 77(4), 727-743.

Scheufele, D. A. (2002). Examining differential gains from mass media and their implications for participatory behavior. Communication Research, 29(1), 46-65.

Scheufele, D. A., Hardy, B. W., Brossard, D., Waismel-Monor, I., \& Nisbet, E. (2006). Democracy based on difference: Examining the links between structural heterogeneity, heterogeneity of discussion networks, and democratic citizenship. Journal of Communication, 56(4), 728-753.

Scheufele, D. A., Nisbet, M. C., Brossard, D., \& Nisbet, E. C. (2004). Social structure and citizenship: Examining the impacts of social setting, network heterogeneity, and informational variables on political participation. Political Communication, 21(3), $315-338$.

Shah, D. V., Cho, J., Eveland, W. P., Jr., \& Kwak, N. (2005). Information and expression in a digital age: Modeling internet effects on civic participation. Communication Research, 32(5), 531-565.

Shah, D. V., Kwak, N., \& Holbert, R. L. (2001). "Connecting” and “disconnecting” with civic life: Patterns of Internet use and the production of social capital. Political Communication, 18(2), 141-162.

Sunstein, C. R. (2001). Republic.com. Princeton, NJ: Princeton University Press. 
Wellman, B., Quan-Haase, A., Boase, J., Chen, W., Hampton, K., de Diaz, I. I., et al. (2003). The social affordances of the Internet for networked individualism. Journal of Computer-Mediated Communication, 8(3). Retrieved from http://jcmc.indiana.edu/vol8/ issue 3/wellman.html.

Wilken, R. (2011). Bonds and bridges: Mobile phone use and social capital debates. In R. Ling \& S. Campbell (Eds.), Mobile communication: Bringing us together or tearing us apart? (pp. 127-150). New Brunswick, NJ: Transaction.

Wojcieszak, M. (2009). Carrying online participation offline: Mobilization by radical online groups and politically dissimilar offline ties. Journal of Communication, 59(3), 564-586.

Wyatt, R. O., Katz, E., \& Kim, J. (2000). Bridging the spheres: Political and personal conversation in public and private spaces. Journal of Communication, 50(1), 71-92.

Xenos, M., \& Moy, P. (2007). Direct and differential effects of the Internet on political and civic engagement. Journal of Communication, 57(4), 704-718. 
유동화된 사회에서의 정치적 관여: 모바일 커뮤니케이션, 네트웍 특징들, 그리고 정치적

참여사이의 상호관계

요약

최근들어 모바일 커뮤니케이션은 네트웍 연계 사이에서의 정치적 담론을 위한 채널로

등장했다. 일부는 정치적 생활에 대한 새로운 가능성들을 찬양하고 있으며, 다른 쪽에서는

이러한 현상이 네트웍 분리와 정치적 무관심을 초래할 것을 우려하고 있다. 본 연구는

어떻게 강한 연계를 가지고 있는 모바일-중재 담론이 정치적 참여의 수준을 예측할 수

있는지를 살펴보았다. 결과들은 모바일에 근거한 담론이 정치적 참여와 긍정적으로

연계되어 있으나, 그 관계는 사람들의 네트웍 사이즈와 이질성에 의해 중재 되었다는 것을

보여주고 있다. 참여는 대규모 네트웍에서 기술사용과 함께 증가하였으나 동질적인

네트웍상에서 기술사용을 하는 경우는 감소하였다. 미래연구를 위한 함의들 이

제공되었다. 


\section{El Compromiso Político en la Sociedad "Movilizada”:}

Las Relaciones Interactivas entre la Comunicación Móvil, las Características de la Red, y la Participación Política

Scott W. Campbell \& Nojin Kwak

Department of Communication Studies, University of Michigan, Ann Arbor, MI 48104

\section{Resumen}

En años recientes la comunicación móvil ha emergido como un canal de discurso político entre los lazos de la red. Mientras algunos celebran las nuevas posibilidades para la vida política, otros están preocupados ya que puede llevar al aislamiento de la red y a la separación política. Este estudio examinó cómo el discurso mediado por los móviles con lazos fuertes interactúa con las características de esos lazos para predecir los niveles de participación política. Los hallazgos revelan que el discurso basado en la movilidad es positivamente asociado con la participación política, pero que esta relación es moderada por el tamaño y la heterogeneidad de la red de pertenencia. La participación incrementa con el uso de la tecnología en las redes grandes de individuos similares, pero declina con el uso de la tecnología en redes homogéneas que son pequeñas. Las implicancias y consideraciones para la investigación futura son ofrecidas en la discusión. Palabras claves: Comunicación móvil; teléfono móvil; teléfono celular; sociedad civil; participación política; redes sociales; lazos fuertes; heterogeneidad 
L’implication politique dans une société « mobilisée » : les associations interactives entre la communication mobile, les caractéristiques des réseaux et la participation politique Scott W. Campbell \& Nojin Kwak

Ces dernières années, la communication mobile est devenue un lieu de discours politique au sein des liens sociaux. Si certains y voient de nouvelles possibilités réjouissantes pour la vie politique, d'autres s'inquiètent de ce que cela pourrait mener à l'insularité sociale et au détachement politique. Cette étude a examiné les manières par lesquelles le discours mobile, au sein de liens forts, interagit avec les caractéristiques de ces liens pour prévoir les degrés de participation politique. Les résultats révèlent que le discours mobile est lié positivement à la participation politique, mais que cette association est modérée par la taille et l’hétérogénéité de son réseau. La participation augmente avec l'usage de la technologie dans de grands réseaux d'individus du même avis, mais décline avec l'usage de la technologie dans les petits réseaux homogènes. La discussion présente des implications et des considérations pour la recherche future.

Mots clés : communication mobile, téléphone mobile, téléphone cellulaire, société civile, participation politique, réseaux sociaux, liens forts, hétérogénéité 
“移动”社会中的政治参与：移动传播、网络特性和政治参与的相互作用

\author{
Scott W. Campbell \& Nojin Kwak
}

密歇根大学传播研究系

\title{
【摘要 :】
}

近年来，移动传播已成为网络关系中政治话语的通道。虽然对这种政治生活的新可 能性不乏拥护者, 但是也有人担心这可能会导致网络与外界隔绝和政治冷漠。本研究旨 在探讨有强列关系的移动媒介话语如何与这种关系的特点相互作用来预测政治参与水 平。调查结果显示, 基于移动媒介的话语与政治参与呈正相关, 但这种关系由网络的大 小和多样化所调节。在成员相似的较大的网络中, 对移动媒体的应用能够增加参与, 但 是在成员各不相同的小型网络中对技术的使用反而减少参与, 最后本文讨论了研究的意 义和未来的研究方向。 
Politische Teilhabe in einer "mobilen" Gesellschaft: Die interaktiven Beziehungen zwischen Mobilkommunikation, Netzwerkeigenschaften und politischer Partizipation

In den vergangenen Jahren hat sich die Mobilkommunikation zu einem Kanal für den politischen Diskurs in Netzwerkbeziehungen entwickelt. Während dies einige als neue Möglichkeiten für das politische Leben feiern, sind andere besorgt darüber, dass dies zu Netzwerkinseln und politischer Entfremdung führen kann. In dieser Studie untersuchen wir, wie ein mobil-mediatisierte Diskurs mit starken Beziehungen mit den Eigenschaften dieser Beziehungen interagiert, um das Maß an politischer Partizipation vorherzusagen. Die Ergebnisse zeigen, dass ein auf Mobilkommunikation basierender Diskurs positiv mit politischer Partizipation zusammenhängt, diese Beziehung allerdings wird durch die Größe und Heterogenität des eigenen Netzwerks beeinflusst wird. Partizipation erhöht die Nutzung von Technologie in großen Netzwerken mit ähnlich denkenden Menschen, vermindert aber den Gebrauch von Technologie in homogenen Netzwerken, die eher kleiner sind. Implikationen und Vorschläge für weiterführende Forschung werden im Diskussionsteil erörtert.

Schlüsselbegriffe: Mobilkommunikation, Handy, Mobiltelefon, Zivilgesellschaft, politische Teilhabe, soziale Netzwerke, starke Beziehungen, Heterogenität 